\title{
Collaborative practical theology. Engaging practitioners in research on Christian practices
}

DOI:

10.1080/1756073X.2020.1818033

Link to publication record in Manchester Research Explorer

\section{Citation for published version (APA):}

Stuerzenhofecker, K. (2020). Collaborative practical theology. Engaging practitioners in research on Christian practices. Practical Theology. https://doi.org/10.1080/1756073X.2020.1818033

\section{Published in:}

Practical Theology

\section{Citing this paper}

Please note that where the full-text provided on Manchester Research Explorer is the Author Accepted Manuscript or Proof version this may differ from the final Published version. If citing, it is advised that you check and use the publisher's definitive version.

\section{General rights}

Copyright and moral rights for the publications made accessible in the Research Explorer are retained by the authors and/or other copyright owners and it is a condition of accessing publications that users recognise and abide by the legal requirements associated with these rights.

\section{Takedown policy}

If you believe that this document breaches copyright please refer to the University of Manchester's Takedown Procedures [http://man.ac.uk/04Y6Bo] or contact uml.scholarlycommunications@manchester.ac.uk providing relevant details, so we can investigate your claim.

\section{OPEN ACCESS}


This is an Accepted Manuscript of a book review published online by Taylor \& Francis in Practical Theology on 1 October 2020, available online:

https://www.tandfonline.com/doi/full/10.1080/1756073X.2020.1818033

Collaborative Practical Theology. Engaging Practitioners in Research on Christian Practices. By HENK DE ROEST. 371pp. Leiden: Brill. 2019. f62 (PBK). ISBN: 9789004413221. f119 (EBook). ISBN: 9789004413238

At the heart of Collaborative Practical Theology is the claim that it has not been common in the discipline to investigate Christian practices collaboratively (129), and the book makes the case for the benefits of doing so. It aims to achieve this first with a historical survey of academic practical theology that identifies the lack of connection between "theological education, practitioners and everyday believers" (ibid) in spite of the discipline's orientation towards lived religion and its aim for relevance to practitioners. At the same time, practical theology's foundations and development support collaborative approaches. In the second part, de Roest offers concrete suggestions why and how to conduct collaborative practical theological research.

De Roest limits his treatment of practical theology to the Christian tradition with a "focus on practices that are in part defined by, and provided with orientation from, the story of Jesus Christ (4)." This includes "Christian practices that occur within ecclesial institutions, but also (...) those which occur on the margins of those institutions, in para-church settings or in issue-focused organizations, in which Christian identity is invoked (5)."

The first chapter introduces as the central aspect of the discipline's contribution to theological studies its practical relevance to contemporary issues, what de Roest calls 'valorisation'. This can be established by collaborating with the intended beneficiaries from the start. Such research is conducted "for the benefit of the world" (11) by aiming for the transformation of society. While firmly grounded in Christian theology, De Roest also speaks to the current academic agenda of 'knowledge transfer'.

The theme of knowledge transfer is further developed in Chapter 2 from the perspective of seminaries and of the academy as platforms for theological education of prospective ministers, chaplains and theologians. I comment further on this apparent academic-practitioner continuum at the end. The chapter covers seven past and present examples of Protestant and Catholic practical theology in Europe, North America and Africa that indicate ways of making theological education "more relevant for students who will become ministers, chaplains or theologians working in different societal organisations (50)." They point the way for knowledge transfer in collaborative practical theology to bridge the gap between "theological education and the competences that students learn on the one hand, and religious practices, such as worship, preaching, pastoral care, congregational leadership, mission work, congregational and personal spirituality, etc., on the other hand (73)."

In the short third chapter, de Roest explores the characteristics of "continuing education for practitioners in various ecclesial or church-related practices (75)", especially the value of conducting this in communities of practice. Again, the roles are shown to merge when de Roest interrogates what might be the place of research in continuing education. When practitioners become researchers, the author suggests that they "can benefit from this new approach, either by conducting research with a practical theologian or together with other practitioners (89)." 
This is an Accepted Manuscript of a book review published online by Taylor \& Francis in Practical Theology on 1 October 2020, available online:

https://www.tandfonline.com/doi/full/10.1080/1756073X.2020.1818033

Chapter 4 provides another historical survey of the discipline in Europe and North America, expanding on the kind of practices studied. In the long first phase from the nineteenth century to the 1960s, de Roest finds "surprising gems" (90) for his later formulation of a rationale for collaborative research. Here the 'clerical paradigm' debate makes a noteworthy appearance: in de Roest's view the narrow remit of practical theology at the time was relevant to its intended audience's needs. As the scope of practical theology has moved outwards from the clerus, relevance needs to be adjusted correspondingly.

On a practical note, Part I ends with an overview of the following chapters, something that is missing from the Introduction. I would have very much appreciated the author's guidance on how to identify only those sections that are relevant to readers who do not need convincing of the value of collaborative research, and want to dive straight into the how-to material.

The issue of relevance in the contemporary context is taken forward in Part II, "namely to connect theological education, practitioners and everyday believers and to point out the strong prospects for collaborative practice-orientated research (129)." Logically, the starting point is with the current information needs of practitioners in Chapter 5. De Roest offers a strong caveat against the limitation of practical theology to a "science of crisis" (146). While he considers this to be an important aspect in order to support practitioners, he also advocates for attention to positive aspects of Christian practices that do not need fixing, but warrant deeper understanding in order to maximise their benefits. In this way, practitioners' engagement with academic research allows them to increase their practical wisdom (155).

In Chapter 6 de Roest moves beyond the question of relevance, and considers whether it is enough to leave implementation to practitioners unless they are also involved in the research (157). To this end, he proposes six rationales why academic practical theology needs a 'turn to the community' (158). In line with de Roest's emphasis on the Christian core of the discipline, the first rationale is developed out of the missio dei. The work of Swinton and Mowat, Theological Action Research, Miroslav Volf, and Paul Fiddes provide guidance for this rationale. Second, mission links directly to the development of an ecclesial community through and in the process of researching together. The third rationale returns to the demand for relevance in the construction of knowledge. De Roest reiterates that academic research depends on the preceding practitioner-knowledge, yet he also emphasizes the value of the creative coming together of a variety of interpretations and partial understandings. For this epistemological rationale, he draws on the work of philosophers Charles Peirce, Joshua Royce and Jürgen Habermas. Moving on to the aims of research, collaboration between practitioner-peers is particularly significant for innovation and professionalization. As concerns the research process, "one's choice of methodology is seen as a political act" (174). Collaborating with the research subjects has the potential to change power differentials, and to avoid the harm of Othering in the research process. It might also actively aim for healing and empowerment. De Roest's final utility rationale recaps his valorisation argument: where practical theological research aims "to enable faithful living and authentic Christian practice" (180), it needs to be "both practice-oriented and theory-driven" (181).

After this very engaging and useful manifesto, Chapter 7 promises a broad inventory of 14 collaborative research frameworks and related methods. However, the limited space of only 60 
This is an Accepted Manuscript of a book review published online by Taylor \& Francis in Practical Theology on 1 October 2020, available online:

https://www.tandfonline.com/doi/full/10.1080/1756073X.2020.1818033

pages reduces each sub-section to the briefest outline and some references. The reader certainly finds useful suggestions to follow up, but de Roest provides little more than signposts.

Having made a convincing case for collaborative research, the book does not shy away from the detailed discussion of constraints to participation in Chapter 8. This is an important contribution, especially for novices. The chapter illustrates the difference that the scientific framework makes to the evaluation of the research process and findings. Discussions of criteria for reliability and validity appear here and also in the final chapter.

That de Roest restricts his treatment of researching teachers, chaplains and ministers to the final thirty pages seems justifiable on the basis of the differences in skills set, context and positionality compared to academics. In fact, he admits that this chapter is an afterthought (323). However, I would question the underlying assumption of a strict separation of roles. De Roest's own biography as presented in the Introduction reveals his movement between the academy and ministry, and his grounding as a practicing Christian. I would have welcomed consideration of the ways in which this multiplicity of roles and perspectives is common among his main readership, and what the implications are for collaborative research. Given the passion that is evident in de Roest's autobiographical account of collaborative working, his reflections on the impact of his past experience as a minister and of his striving for authentic Christian living in the quotidian on his academic work would have promised useful insights into the complexities of practical theological knowledge construction.

Collaborative Practical Theology is strongest in the use of practice examples from ecclesial and other contexts in a range of locations in continental Europe, the British Isles, Africa and North America. These examples bring de Roest's argument to life, and provide glimpses into the nitty gritty. Conversely, engagement with the literature sometimes lacks criticality, and it does not always do justice to the state of the art. Especially the historical surveys offer lengthy descriptions of a wide range of material, but often without the author's explicit evaluation. On other occasions, such as in his introduction of 'communities of practice' in Chapter 5, de Roest acknowledges the primary sources, but makes no reference to their existing treatment by other practical theologians.

Regarding the intended readership, De Roest explicitly addresses academy-based practical theological researchers and their stakeholder-collaborators. (293). I would add that the book is primarily of use to those who still need convincing that collaborative research across the academy practice divide is beneficial. Readers like myself who already use such approaches, but seek to invigorate and expand their repertoire might be tempted to skip large parts of the book, only to be disappointed by the lack of depth in the exposition of approaches in Chapter 7.

Katja Stuerzenhofecker

University of Manchester, UK

katja.stuerzenhofecker@manchester.ac.uk 